\title{
Tetragenococcus muriaticus sp. nov., a new moderately halophilic lactic acid bacterium isolated from fermented squid liver sauce
}

Masataka Satomi, Bon Kimura, Michiko Mizoi, Tsuneo Sato and Tateo Fujii

International Journal of Systematic Bacteriology (1997), 47, 832-836

p. 833, column 2, line 15 should read 'The major fatty acids of new isolates were 14:0, 16:0,16:1(n-7), 18:0, $18: 1(\mathrm{n}-7, \mathrm{n}-9) \ldots$ ' not 'The major fatty acids of new isolates were $14: 0,16: 0,16: 1(\mathrm{n}-9), 18: 0,18: 1(\mathrm{n}-11, \mathrm{n}-9) \ldots$ '

p. 833 , Table 3, column 1, line 9 should read ' $18: 19(\mathrm{n}-7)$ ', not ' $18: 1(\mathrm{n}-11)$ '

p. 835 , column 1 , line 14 should read 'mannitol', not 'lactose' 